Table 1. RHIzobral Prontetion of YAA From Tryptophan, Nitkite FROM NITRATE OR AMMONIUM, AND THE RESIDUAL TRYPTOPHAN

Reaction mixture

$\begin{array}{ccc}\begin{array}{c}\text { IAA } \\ \text { produced }\end{array} & \begin{array}{c}\text { Nitrite } \\ \text { produced } \\ (\mu \text { moles/ml. })\end{array} & \begin{array}{c}\text { Residual tryptophan } \\ (\mu \mathrm{moles} / \mathrm{ml} .)\end{array} \\ 0.054 & 0.000 & 0.47 \\ 0.015 & 0.066 & 0.48 \\ 0.019 & 0.000 & 0.76\end{array}$

$\left(\mathrm{KNO}_{3}\right)$, and (3) tryptophan + ammonium $\left(\mathrm{NH}_{4} \mathrm{Cl}\right)$. The final concentrations of the constituents in the reaction mixtures were as follows: tryptophan, $10^{-3} \mathrm{M} ; \mathrm{KNO}_{3}$, $10^{-2} \mathrm{M} ; \mathrm{NH}_{4} \mathrm{Cl}, 10^{-2} \mathrm{M}$; mannitol, 1 per cent; and $10^{6}$ cells $\mathrm{ml}$. After $24 \mathrm{~h}$ the reaction mixtures were centrifuged at $20,000 \mathrm{~g}$ to remove the cells. Aliquots of the supernatants woro used for IAA, nitrite, and tryptophan determina. tions.

The results of the IAA, nitrite, and tryptophan determinations are shown in Table 1. The addition of nitrate did not affect the conversion of tryptophan to IAA as evidenced by the same residual tryptophan with and without nitrate. However, the IAA present was much lower when nitrate was added. This was the result of the nitrite catalysed destruction of the IAA. When ammoninm was present, there was a reduction in TAA level, but this apparently was due to a decrease in the amount of tryptophan converted to IAA.

If IA $\Lambda$ is necessary for infection, these results indicate that the effect of combined nitrogen in reducing IAA would result in redueed infection. This would be an extornal (local) effect of combined nitrogen as opposed to the established internal effect. The external effect acts on the infection process. The internal effect acts on nodule development. The two theories (internal and external) are not contradictory, but, instead, would appoar to be quite complomentary and compatible.

This work was partially supported by a grant from the U.S. Department of Health, Education, and Wolfaro (GMO9063-02).

J. W. TANNER *

I. C. Anderson

Department of Agronomy,

Iowa State University,

Annes.

* Present address: Department of Crop Science, Ontario Agricultural College, Guelph, Ontario, Canada.

1 Gibson, A. H., and Nutman, P. B., Ann. Bot. (N.R.), 24, 420 (1960).

${ }^{2}$ Richardson, D. A., Jordan, D. C., art Garrard, E, H., Canad. J, Plant Sici., 37, 205 (1957)

"Fedorov, M. V., and Kozlov, I. V., Mikrobiologia, 23, 534 (1954).

4 Gaumann, E., Jaag, O., and Roth, S., Ber. Schweiz. Bot. Ges., 55, 270 (1945).

${ }^{5}$ Wilson, J. K., New York (Ithaca) Agric. Exp. Sta, Bull.. 386, 369 (1917)

${ }^{6}$ Raggio, M., Raggio, N., and Torrey, J. G., Amer. J. Bot., 44, 325 (1957).

'l'onhazy, N. E., and Pelczar, jun., M. J., Science, 120, 141 (1954).

\section{Epiblast in Gramineae}

The homologies of tho various organs of the graminaceous embryo and caryopsis have been the subject of much debate in the past. Jacquos-Félix ${ }^{1}$, who recently summarized again tho various theorios, has suggested that the epiblast is the sole leaf of the primary axis or "protocorm'; other theories give the epiblast the status of an auricle, or a cotylodon.

In the course of work on the germination of grasses, I have found that some species form well-devoloped hairs on the epiblast. The hairs arise from the epithelial cells on the abaxial side of the epiblast, or from its apex; there is always a hair-free zone between the base of the opiblast and the coleorhiza hairs. The hairs are similar to those of tho coleorhiza and they are often as long. The numbers and regularity with which the hairs are formod seom to vary with the specios. Some species appear never to form thom; othors, such as Lolium perenne, have only about 5 per cent of the epiblasts with hairs, and with othor spocios most epiblasts havo them.

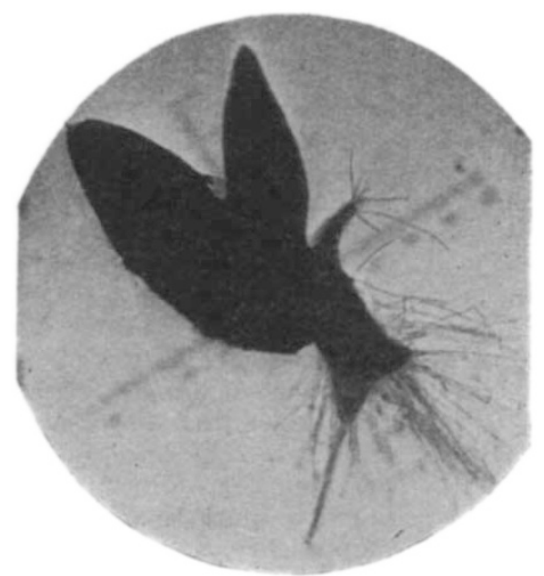

Fig. 1. Hairs on epiblast of Chloris myriostachya

Apparently the only reference to these hairs is by Nishimura", who states that the "epiblast may develop absorbing hairs from its apical cell or from any of its colls; and in fact it responds to environmental factors in the same manner as does the coleorhiza". He gives a figure showing hairs on the epiblast of Phleum pratense. The hairs on the coleorhiza are assimilatory ones and there is no reason why those on the epiblast should not also be so. I have so far found hairs on the epiblasts of Chloris myriostachya Hochst., Oypholepis yemenica (Schweinf.) Chiov., Leptochloa obtusiflora Hochst., Lolium perenne L., and Phleum pratense $\mathrm{L}$. If, as my observations indicato, these hairs are far commonor than is genorally realized, the strictly foliar homology of the epiblast is questionable: it may really be an absorbing organ.

I thank Dr. R. L. Tucas, of the Department of Agri. culturo, University of Oxford, and Dr. H. J. Hudson, of the Botany Department, University of Cambridgo, for searching the literature which is not available in East Africa.

Grassland Researeh Station,

W. R. BHRm

Box 450,

Kitale,

Kenya.

'Jacques-Félix, M. H., Eighty-third Cong. Soc. Savants (1958).

N Nishimura, M., Jap. J. Bot., 1, 5 is (1922).

\section{A Rhizosphere Effect of the Pea Root on Soil Algae}

STAREEY ${ }^{1}$, in a review of the effects of the rhizosphere on the soil microflora, found that a stimulatory effect could be obsorved on the gross populations of bacteria, actinomycetes, yeast and fungi in the soil. For the algae, how ever, no evidenco was presented, although Starkey surm. ized that any effects may be either directly or indiroctly deleterious. Hadfield ${ }^{2}$ showed that the seedlings of the toa plant could significantly increase the algal population on the surface of the soil. The size of the population was estimated by the soil dilution method.

To examine whethor the rhizosphere could have any influenco on algæ, the following experiment was devised. Germinated seedlings were grown under sterile conditions on the surface of minoral agar, scoded with a crude culture of algao, and incubated for ten days under a very low level of illumination (0-5 metre-candles). Pea seedlings were used since Wallaco and Jochherd ${ }^{3}$ found that leguminous plants possessed a rhizosphere effect greater than most plants. The seeds were first sterilized, using $0-1$ per cent mercurie chloride, and gorminated on moist filter paper under sterile conditions. As soon as swelling and germination had occurred, the seed was transferred to the agar surface. The minoral agar was made according to the 